\title{
Bioactivator on physiological performance of tomato and onion seeds
}

Lilian Madruga Tunes, Andréia da Silva Almeida, Géri Eduardo Meneghello, Francisco Amaral Villela, Vanessa Nogueira Soares*, Murilo Bortolotti

\begin{abstract}
Vegetable seeds have high commercial value, in the field after sowed seeds were exposed to unfavorable environmental conditions capable of causing reductions in the yield. Thiamethoxam is a bio-activator that may confer tolerance to stresses. In this regard, we aimed to evaluate the influence of thiamethoxam in the physiological performance of four lots of tomato and onion seeds. Seeds were treated with five doses of thiamethoxam, $0.0 ; 0.2 ; 0.4 ; 0.6$ and $0.8 \mathrm{ml}$ of product per 1000 seeds. The effects of the seed treatments were evaluated by the assessments of the first count of germination, sprouting test, cold test, accelerated aging and seedling's emergence in the greenhouse. The experimental design was completely randomized, with four replicates per lot and by species. Data were submitted to analysis of variance and adjusted by orthogonal polynomials, using the adjusting equation based on the significance of $\mathrm{F}$ test at $5 \%$ probability. The bioactivator provided an increase in germination percentage, the first count of ermination, germination after accelerated aging, cold test and seedling's emergence for low vigor seed lots. The bioactivator thiamethoxam stimulates the physiological performance of tomato and onion seeds. Doses of 0.5 to $0.6 \mathrm{~mL}$ of thiamethoxam per 1000 seeds of tomato and onion correspond to technical maximum efficiency.
\end{abstract}

Keywords: Allium cepa L., Solanum lycopersicon, thiametoxam, vigour

\section{Introduction}

In vegetables, the delay and the lack of uniformity in the initial plant development can reflect in the final product quality and so well reducing its commercial value, for example in lettuce, cabbage, carrot, cauliflower, eggplant and onion (Kikute \& Marcos Filho, 2007). Among vegetables species propagated by seeds, the onion (Allium cepa L.) calls attention in both national and international scenario, aside with tomato (Solanum lycopersicon) due to economic importance given by high production and by income it guarantee (Rodrigues et al., 2007).

Because of the onion floral biology, the seeds from the same umbel have different maturation fimes, which can cause difference

in the seeds quality from the same inflorescence (Nascimento \& Freitas, 2008). The tomato seeds, as other vegetables, own the high commercial value and often are imported, a regular event to the hybrids, showing the needing of high physiological quality of the seeds (Martins et al., 2006).

One of the limiting factors for the success of the vegetables species has been the difficulty to obtain seeds capable of provides the establishment of culture with the ideal population and with uniform and vigorous seedlings (Alves et al., 2012). To occur a better expression of the set of attributes that ascertain the seed potential 
performance after its sowing in a field or during the storage phase, it is necessary the seed treatment, which is important by the facility of execution, low cost and high efficiency over several aspects, as further the control over pathogens and pests, allowing even to help the seedling's emergence and the development of the plants exposed to the hydric stress (Balardin et al., 2011).

The bioactivators are organics and complex substances modifiers of the growing, and capable of act in the transcription of the plant DNA, in the genetic expression, in the membrane proteins, in the metabolic enzymes and mineral nutrition (Castro et al., 2005).

The insecticide thiamethoxam has showed a bioactivator effect in the physiological process resulting positively in the increase on the expression of the vigor and in the phytomass gain, increasing the photosynthetic rate and originating deeper roots (Almeida et al., 2009). It has a phytotonic action, resulting in a faster plant development, and consequently a better vigor expressing. According to Almeida et al. (2009), the product thiamethoxam promotes the physiologic performance of carrot seeds subjected to a hydric stress and the treated seeds with this product show significant increases in the expression of physiological quality.

In this context, taking the lack of information about the thiamethoxam effect and the potential benefits which the treatment can provide, it was aimed to evaluate its influence in the physiologic performance of onion and tomato seeds.

\section{Material and Methods}

The work was developed at the didactic laboratory of seed analysis and at the greenhouse of the Plant Science Department of the Eliseu Maciel Agronomy College from the Federal University of Pelotas, Campus Capão do Leão. Four commercial lots of each of tomato and onion seeds were used in the experiments. The seeds were treated with five doses $(0.0,0.2$; $0.4 ; 0.6$ and $0.8 \mathrm{~mL}$ ) of the product thiamethoxam (Cruiser $^{\circledR} 350$ FS) with 1000 seeds. The spray (product + distilled water) was applied using a graduated pipette at the bottom of a transparent plastic bag and distributed at the transparent plastic bag walls until the height of $15 \mathrm{~cm}$. The spray volume used was of $0.1 \mathrm{~mL} / 1000$ seeds. After that, the seeds were manually shaken for two minutes.

The treatments effects were evaluated by the following assessments:

Water content - using the oven method over $105 \pm 3^{\circ} \mathrm{C}$ for 24 hours with two samples of 4.5 $\mathrm{g}$ for each seed lot, following the methodology suggested by RAS (Brazil, 2009).

Seed germination - 50 seeds of each seed lot were used four samples, distributed in gerbox-type clear plastic boxes, over two sheets of damped blotting paper with 2.5 times the weight of the dry paper. After the components have been mounted, the plastics bags with the tomato seeds were covered and put in a BOD chamber set to keep the temperature between $20-30^{\circ} \mathrm{C}$ with eight hours of light and sixteen hours in the dark. The gerbox containing the onion seeds were taken to a germinator set at the constant temperature of $20^{\circ} \mathrm{C}$. The counting were made at the fifth ant fourteenth day and in the sixth and twelfth day after the sowing for the tomato and the onion seeds, respectively. The experiment installation and the evaluations were made according to the rules for seed analysis (Brazil, 2009), computing the percentages of normal seedlings for each replicate.

First count of germination - Carried out together with the germination test, it is the record the normal seedling percentage registered in the first counting of the germination test, made for tomato and onion seeds, respectively on the fifth and sixth day after sowing. The evaluations were made according to the rules for seed analysis (Brazil, 2009), computing the percentages of normal seedlings for each replicate.

Cold test - Used four samples of 50 seeds for each treatment, in transparent plastic bags over two sheets of moistened blotting paper with 2.5 times the height of the dry paper, and kept in a refrigerator set at $10^{\circ} \mathrm{C}$, for seven days. After that, the tomato seeds were put in a BOD chamber set at $20-30^{\circ} \mathrm{C}$ with eight hours of light and sixteen hours of dark. The onion seeds were placed in germinator set at $20^{\circ} \mathrm{C}$. The evaluations were made following the rules for seed analysis (Brazil, 2009). The counting of normal seedlings 
was assessed at the fifth (tomato) and sixth (onion) days after the installation of the test and the results showed as percentages.

Accelerated aging - conducted with $4.0 \mathrm{~g}$ of seeds, distributed in a suspended wire mesh and placed inside gerbox-type clear plastic boxes. Inside the gerbox, $40 \mathrm{~mL}$ of water were added and, right after, the boxes were taken to an incubator, regulated at an ongoing temperature of $41^{\circ} \mathrm{C}$, over $72 \mathrm{~h}$ and after that submitted to the germination test, as previously described. The evaluation was realized at the fifth (tomato) and sixth (onion) days after the sowing, computing the percentage of normal seedlings (Krzyzanowsky et al., 1999).

Seedling's emergence in greenhouse - four samples of 50 seeds where distributed in trays, containing commercial substrate Plantmax ${ }^{\circledR}$. The trays were kept in a greenhouse and the evaluations were made after fourteen days after the sowing, computing seedlings with length equal or higher to $2.0 \mathrm{~cm}$. The results were indicated in percentage of seedling emergence (Krzyzanowsky et al., 1999).

The experimental design used was completely randomized, with four replicates for each lot and species. The data were submitted to analysis of variance and adjusted by orthogonal

Table 1. Initial physiological quality of tomato and onion seeds lots.

\begin{tabular}{|c|c|c|c|c|c|c|c|c|}
\hline \multirow{3}{*}{ Evaluation } & \multicolumn{4}{|c|}{ Tomato } & \multicolumn{4}{|c|}{ Onion } \\
\hline & \multicolumn{4}{|c|}{ Lots } & \multicolumn{4}{|c|}{ Lots } \\
\hline & 1 & 2 & 3 & 4 & 1 & 2 & 3 & 4 \\
\hline Water percentage (\%) & 9.4 & 9.1 & 9.6 & 9.5 & 5.7 & 6.0 & 6.0 & 5.8 \\
\hline Germination (\%) & 96 & 96 & 86 & 87 & 96 & 98 & 85 & 84 \\
\hline 1st count of germination (\%) & 94 & 94 & 82 & 81 & 92 & 90 & 80 & 81 \\
\hline Cold test (\%) & 92 & 93 & 81 & 82 & 91 & 92 & 80 & 84 \\
\hline Accelerated aging (\%) & 94 & 93 & 82 & 83 & 92 & 90 & 81 & 80 \\
\hline Seedling emergence in greenhouse (\%) & 94 & 94 & 83 & 82 & 94 & 94 & 81 & 82 \\
\hline
\end{tabular}

The greatest increase on the germination percentage of the less vigorous lots of tomato (Figure 1A) and onion (Figure 1B) was observed in the seeds treated with thiamethoxam. It was observed that the more vigorous lots showed minor increases compared to the zero dose. However, the lots that showed the minor vigour, the gains in the germination percentage and vigour were significant, reaching 13 percentage points for both tomato and onion seeds.

The highest increases occurred in the similar doses for both species, reaching polynomials, using the adjusted equation based in the F-test with a significance level of $5 \%$. When there wasn't significance in the data, they were expressed just through the exposition of points. For the execution of the statistical analysis system for Windows (WinStat, v 1.0) (Machado \& Conceição, 2003) was used.

\section{Results and Discussion}

According to data contained in the Table 1, the tomato and onion seeds lots had a different initial quality, being possible to distinguish between the lots 1 and 2 , as the most vigorous and the lots 3 and 4 , as the less vigorous, according to the value of seedlings emergence, for both species. The seeds vigour can be comprehended as that propriety of the seeds that ascertain the potential for a faster and equal seedling emergence and for the development of normal seedlings over a wide range of field conditions (AOSA, 2009). In this way, the seedling emergence is the best test to simulate the establishment of seedlings on the field, which do not happen when the standard germination test is used, because it is conducted in ideal conditions of substrate, temperature and humidity, making able the maximum expression of normal seedlings (Larré et al., 2007). maximum efficiency at the doses 0.65 and $0.51 \mathrm{~mL} / 1000$ seeds, for the lots 3 and 4 of tomato seeds, respectively. For the onion seeds lots, the doses of higher efficiency were 0.64 and $0.52 \mathrm{~mL} / 1000$ seeds respectively for the lots 3 and 4 . The increments in the germination were accentuated and varied according to the lots. For tomato cultivation this increment reached to 11 percentage points in the lot 3 and 9 percentage points in comparing with the untreated seeds. For onion seeds, the increment was around 10 percentage points on the lots 
3 and 4 . The germination of the high vigorous lots (1 and 2) of both treated species with the bioativator did not differ from the zero dose due to the high percentage of initial germination in these lots, with values equal to or higher than $96 \%$.

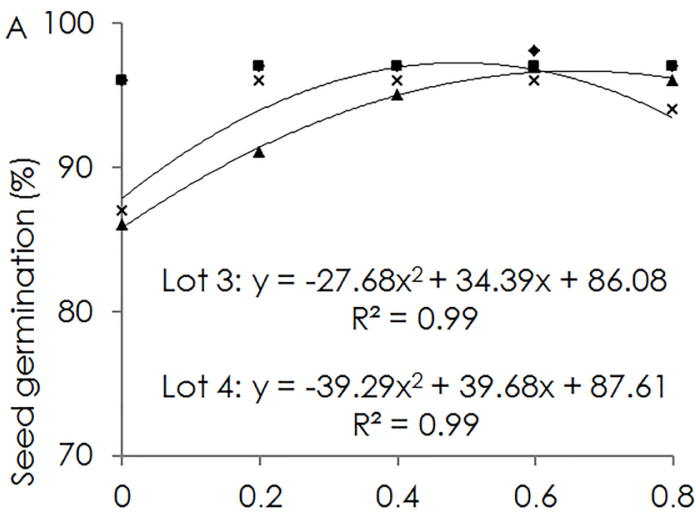

Thiamethoxam doses ( $\mathrm{mL} / 1000$ seeds)

$$
\text { - Lot } 1 \text { - Lot } 2 \quad \Delta \text { Lot } 3 \quad x \text { Lot } 4
$$

In carrots (Almeida et al., 2009) and rice (Almeida et al., 2011) seeds was also observed that the thiamethoxam increased the germination expression.

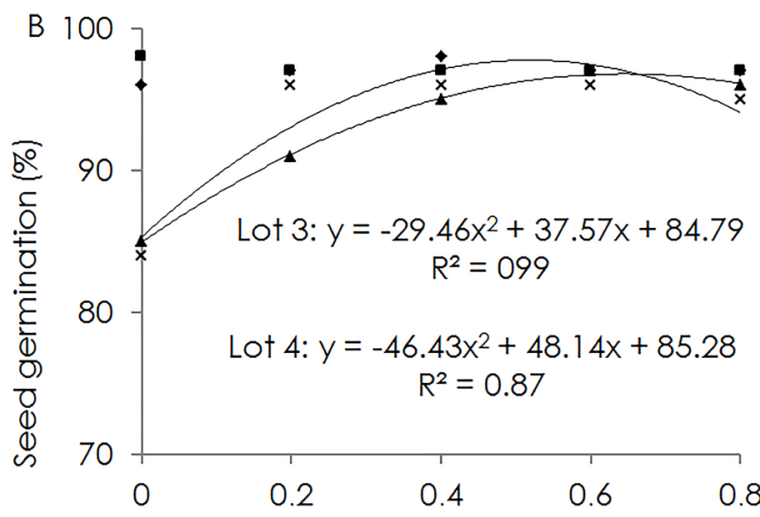

Thiamethoxam doses ( $\mathrm{mL} / 1000$ seeds)

$$
\text { - Lot } 1 \quad-\text { Lot } 2 \quad \Delta \text { Lot } 3 \quad x \text { Lot } 4
$$

Figure 1. Germination (\%) of four lots of tomato seeds (a) and four lots of onion seeds.

According to Figures $2 \mathrm{~A}$ and $2 \mathrm{~B}$, the treatment with the bioativator grant an increase in the percentage of normal seedlings on the first count of germination of tomato and onion seeds, adjusting in a quadratic function curve similar to the germination one. Up from the zero dose, the curve was crescent, giving an increment

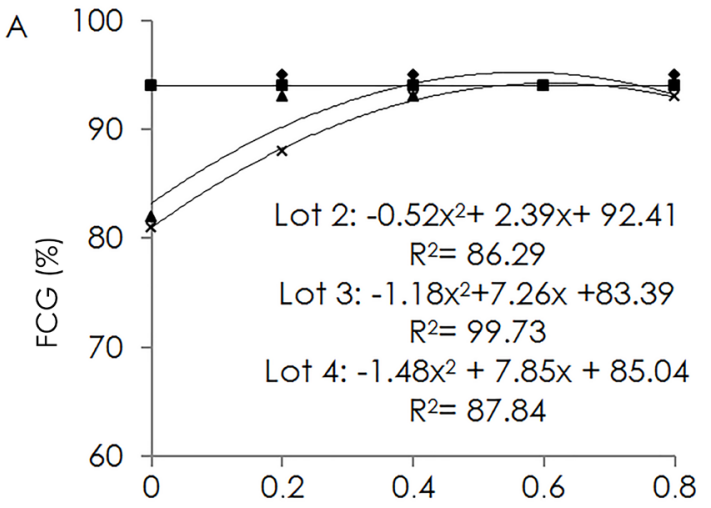

Thiamethoxam doses ( $\mathrm{mL} / 1000$ seeds)

- Lot $1 \quad$-Lot $2 \quad \Delta$ Lot $3 \quad \times$ Lot 4

Figure 2. First count of germination (\%) of four lots of tomato seeds (A) and four lots of onion seeds (B) treated with doses of thiamethoxam.

As it could been seen in the Figures $3 \mathrm{~A}$ and $3 \mathrm{~B}$ the germination after the accelerated aging of the tomato and the onion seeds, respectively, treated with thiamethoxam showed a good variation, according to the lots, with the maximum of 10 percentage points on the lots 3 and 4. The germination increment after the aging of 12 percentage points for the less vigorous lots of tomato (2A) and the onion (2B) seeds in the higher dose. The thiamethoxam possibly speed up the germination of the seeds by the stimulation of enzymatic activity that provides a seedling emergence more uniform and a better initial development (Deuner et al., 2014).

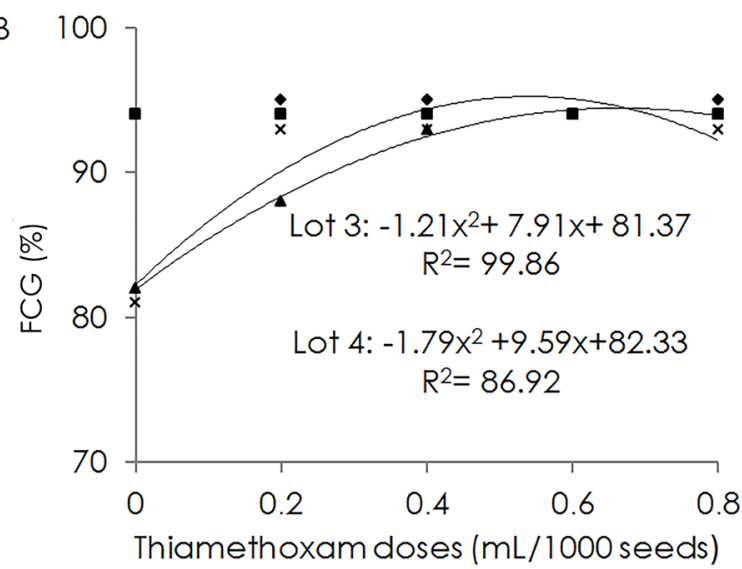

- Lot 1 - Lot 2. Lot $3 \times$ Lot 4

test happened after the zero dose and the points of maximum fluctuated between the doses values from 0.53 to $0.63 \mathrm{~mL} / 1000$ seeds, according to lots and species. In respect to achieved results, it is possible to note the stimulating effect of the thiamethoxam, especially in the less vigorous lots. Probably, this better resistance happened, 
probably, because the thiamethoxam can move between the plant cells and activate many physiological reactions, with the expression of functional proteins related to plant defense mechanisms to act against the factors of stress as

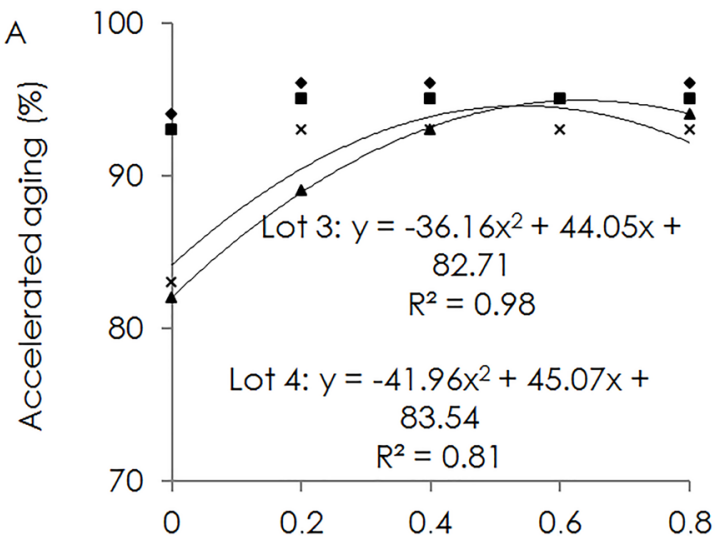

Thiamethoxam doses ( $\mathrm{mL} / 1000$ seeds) droughts, high temperature, toxic effects among others, improving the productivity, leaf and root areas and, as proven in soybean seeds (Castro et al., 2007).

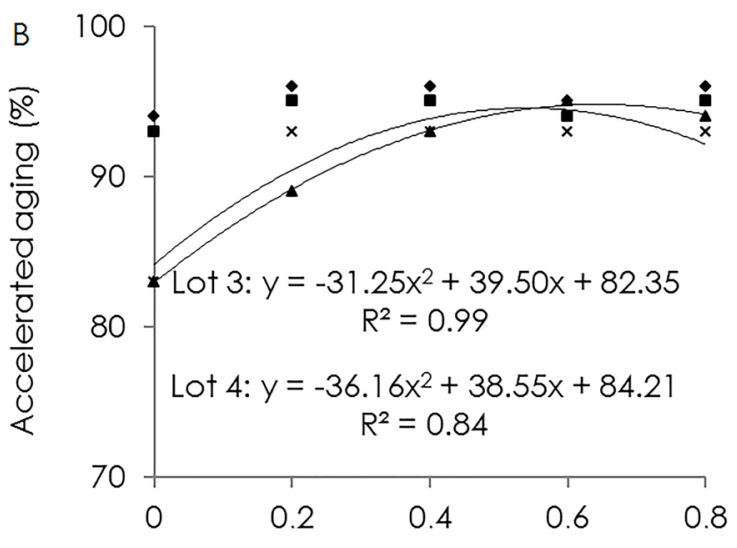

Thiamethoxam doses ( $\mathrm{mL} / 1000$ seeds)

- Lot $1 \quad$ - Lot $2 \quad \Delta$ Lot $3 \quad x$ Lot 4

Figure 3. Accelerated aging (\%) of four lots of tomato seeds (A) and four lots of onion seeds (Treated with doses of thiamethoxam.

The treated seeds showed an accentuated variation in the cold "test" when compared with untreated seeds, reaching an average of 12 percentage points, in the maximum dose of technical efficiency, in the lots 3 and 4 and of 2 to 3 percentage points in lot 2, for the tomato (Figure 4A) and onion (Figure 4B) seeds, respectively. Increments happened

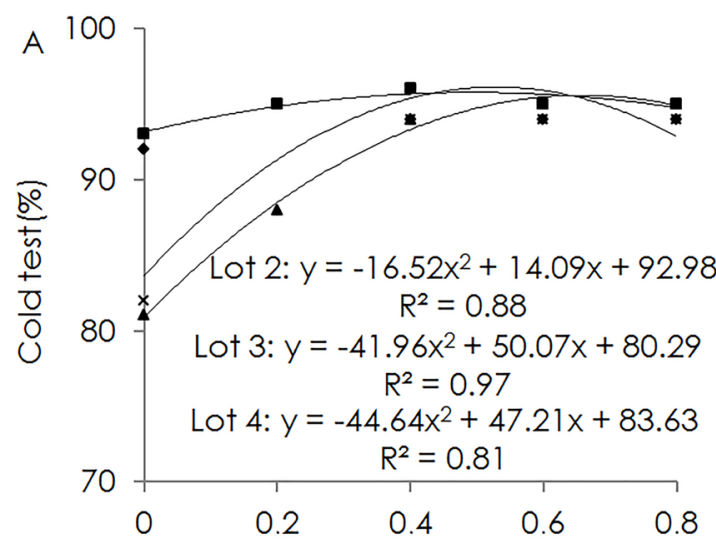

Thiamethoxam doses ( $\mathrm{mL} / 1000$ seeds) after the zero dose until 0.43 to $0.6 \mathrm{~mL} / 1000$ seeds for the lots 2, 3 and 4 of tomato seeds. To onion, the higher values were observed in the doses between 0.51 and $0.68 \mathrm{~mL} / 1000$ seeds for lots 2 , 3 and 4 . These results highlight once again the positive effect of the bioactivator on seeds of less vigorous lots, helping in the germination process.

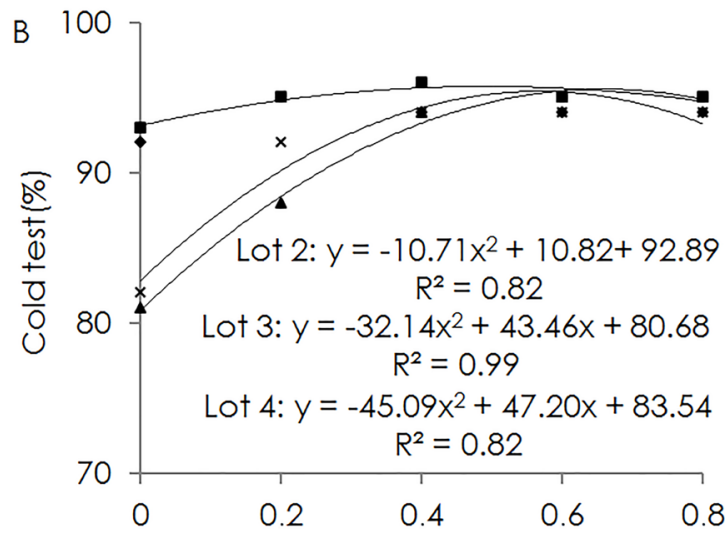

Thiamethoxam doses ( $\mathrm{mL} / 1000$ seeds)

\footnotetext{
- Lot $1 \quad$ - Lot $2 \quad \Delta$ Lot $3 \quad x$ Lot 4
}

Figure 4. Cold "test" (\%) of four lots of tomato seeds (A) and four lots of onion seeds (B)treated with doses of thiamethoxam.

In the Figures $5 \mathrm{~A}$ and $5 \mathrm{~B}$ are represented in the trend curves of seedling emergence to three lots of tomato seeds (Figure 5A) and two lots of onion seeds (Figure 5B). The seedlings had the emergence stimulated when treated with thiamethoxam, with increases according to dose elevation, showing increases from the dose zero until $0.5 \mathrm{~mL} / 1000$ seeds. Positive differences in relation to zero dose occurred, according to the seed lots, from 10 to 12 percentage points in the 
lots 3 and 4 and one percentage point for the lot 2 of tomato. Both species showed similar answers. The increase on seed emergence percentage

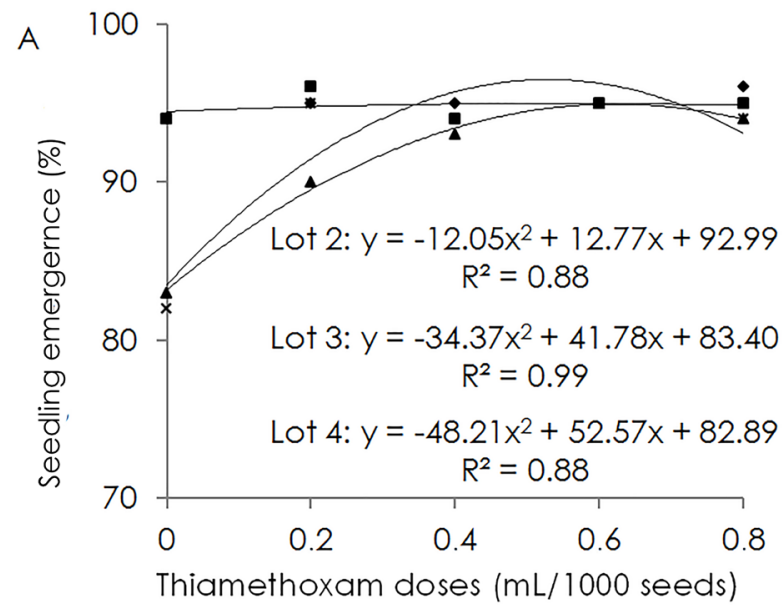

- Lot $\quad$-Lot $2 \quad \Delta$ Lot $3 \quad x$ Lot 4 Figure 5. Seedling emergence (\%) of four lots of tomato seeds (A) and four lots of onion seeds (B) treated with doses of thiamethoxam.

Similarly, soybean seeds treated with thiamethoxam showed higher level of aminoacids, enzyme activity and synthesis of plant hormones which increase the answer of the plants to these proteins, and these events provided significantly increases on the production and lowering the time of culture establishment in the field, making it more tolerant to stress factors (Almeida et al., 2009).

The product was more efficient in stimulating the seed performance in lots with lower vigor. In all parameters, the increases of quality randomized according to the lot and the product dose that presented a better efficiency, and in this respect, it was similar for every evaluated test. The answer curves showed crescent tendency from zero dose to maximum efficiency dose, followed by a small reduction when compared to the maximum efficiency dose, but keeping it higher than the zero dose.

The application of thiamethoxam can be relevant for tomato and onion crops that may show a low germination, slow and irregular, with "uninform" seedling emergence. The product acts as an optimizer, allowing the expression of the seed germination potential, accelerating the root growth and improving the nutrient absorption by plants. These characteristics of thiamethoxam aside to seeds of high physiological attributes can increase the production capacity of these happened after the zero dose and had the maximum effect in doses between 0.53 and 0.60 $\mathrm{mL} / 1000$ seeds for both species lots.

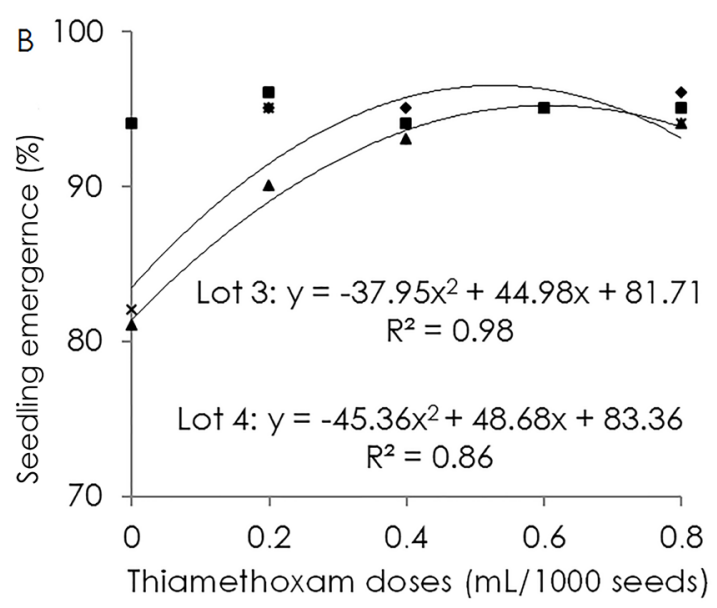

\section{- Lot $1 \quad-\operatorname{Lot} 2 \quad \Delta$ Lot $3 \times$ Lot 4}

crops.

The use of bioactvator substances in seeds of vegetable crops constitutes a potentially advantageous technique because the elevation of the physiological potential expression, particularly with respect to setting speed, it is recommended to surpass the adverse ambient conditions (Deuner et al., 2014).

\section{Conclusions}

The bioactvator thiamethoxam promotes the physiological performance of onion and tomato seeds. Doses about 0.5 to 0.6 $\mathrm{mL}$ of thiamethoxam per 1000 seeds provide the maximum technical efficiency.

\section{References}

Almeida, A.S., Carvalho, I, Deuner, C, Villela, F.A., Tillmann, M.A.A. 2011. Bioativador no desempenho fisiológico de sementes de arroz (Oryza sativa L.). Revista Brasileira de Sementes 33: $501-511$.

Almeida, A.S., Tillmann, M.A.A., Villela, F.A., Pinho, M.S. 2009. Bioativador no desempenho fisiológico de sementes de cenoura. Revista Brasileira de Sementes 31: 87-95.

Alves, J., Barbosa, R.M., Costa, D.S., Sá, M.E. 2012. Condicionamento osmótico e desempenho fisiológico de sementes de rúcula. Biotemas 25: 171-176.

AOSA. Association of Official Seed Analysts. 2009. Seed vigor testing handbook. contribution no. 32 
to the Handbook on seed testing.

Balardin, R.S., Silva, F.D.L., Debona, D., Corte, G.D., Favera, D.D., Tormen, N.R. 2011 .Tratamento de sementes com fungicidas e inseticidas como redutores dos efeitos do estresse hídrico em plantas de soja. Ciência Rural 41: 1120-1126.

Brasil. 2009. Ministério da Agricultura e da Reforma Agrária. Regras para análise de sementes. SNDA/ DNDV/CLAV, Brasília, Brazil. 398p.

Castro, P.R.C., Pitelli, A.M.C.M., Peres, L.E.P., Aramaki, P.H. 2007. Análise da atividade reguladora de crescimento vegetal de tiametoxam através de biotestes. Publicatio UEPG 13: 25-29.

Castro, P.R.C., Pitelli, A.M.C.M., Peres, L.E.P. 2005. Avaliação do crescimento da raiz e parte aérea de plântulas de tomateiro MT, DGT E BRT germinadas em diferentes concentrações do inseticida thiametoxan. In: Escola Superior de Agricultura "Luiz de Queiroz". Relatório técnico ESALQ/Syngenta. Piracicaba, Brazil, p.14-25.

Deuner, C., Almeida, A. S., Borges, C. T., Meneghello, G.E., Villela, F.A. 2014. Desempenho fisiológico de sementes de alface tratadas com tiametoxam. Enciclopédia Biosfera 10: 1173-1182.

Kikute, A. L. P., Marcos Filho, J. 2007. Potencial fisiológico de sementes de couve-flor e desempenho das plantas em campo. Revista Brazileira de Sementes 29: 107-113.

Krzyzanowski, F.C., Vieira, R.D., França Neto, J.B. 1999. Vigor de sementes: conceitos e testes. Abrates, Londrina, Brazil. 218p.

Larré, C. F., Zepka, A. P. S., Moraes, D.M. 2007. Testes de germinação e emergência em sementes de maracujá submetidas a envelhecimento acelerado. Revista Brasileira de Biociências 5(2): 708-710.

Machado, A.A., Conceição, AR. 2003. Sistema de análise estatística para Windows. WinStat. UFPel, Pelotas, Brazil. Version 2.0. CD-ROM.

Martins, C.C., Castro, M.M., Seneme, A.M., Nakagawa, J. 2006. Metodologia para a avaliação do vigor de sementes de tomate. Horticultura Brasileira 24: 301-304.

Nascimento, W.M., Freitas, R.A. 2008. Qualidade fisiológica de sementes de cebola em função do estádio de maturação das umbelas. Horticultura Brasileira 26: 78-82.

Rodrigues, A. P. D'A. C., Piana, C. F. B., Peske, S.T., Lucca Filho, O. A.,Villela, F. A. 2007. Produção de sementes de cebola em sistemas convencional e de transição agroecológica. Revista Brazileira de Sementes 29: 97-110. 